\title{
Effect of Therapeutic Atmosphere in a Psychiatry Clinic on Social Functionality of in-Patients
}

Neslihan Lok ${ }^{\star}$ and Kadriye Buldukoğlu

Akdeniz University, Turkey

*Corresponding author: Neslihan Lok, Akdeniz University, Turkey, Tel: 90505 6451589; E-mail: neslihanlok@akdeniz.edu.tr

Received Date: August 22, 2014, Accepted Date: October 08, 2014, Published Date: October 28, 2014

Copyright: (C) 2015 Lok et al., This is an open-access article distributed under the terms of the Creative Commons Attribution License, which permits unrestricted use, distribution, and reproduction in any medium, provided the original author and source are credited.

\begin{abstract}
Objective: Hospitalization for patients with psychiatric disorders involves situations such as getting away from their usual environment and being together with unfamiliar people. The aim of the present research was to evaluate the effect of therapeutic atmosphere in a psychiatry clinic on social functionality of in-patients. Method: The research has been planned as a descriptive and relational type and conducted with 50 patients who accepted to participate in and who had been hospitalized in Psychiatry Ward.
\end{abstract}

Results: In the light of findings of the present study, a relation was found between therapeutic atmosphere and social functionality. It was determined that there was statistical significance between "social functionality scale" scores of the patients and their gender and medical diagnosis. Social functionality which was acquired in the ward maintained for a month after discharge.

Conclusion: The most important finding of the present study has been that male patients were more socially functional than female patients and that functionality was maintained for one month after discharge. The results of the research carried out in the psychiatric clinic, as well as contribution to the development of patient care team members that may lead to the work.

Keywords: Therapeutic atmosphere; Social functioning; Psychiatric nursing

\section{Introduction}

Psychiatric disorders lead to serious psycho-social limitations for the patients. Deterioration in social functionality takes part in the first order among those limitations. This is also defined as not being able to perform one's social roles. Self-care ability of the subjects who have impaired functionality is weak and participation in spare-time activities is limited [1]. Being included in the diagnostic criteria of DSM-IV-TR and NANDA made the importance of social functionality clear in psychiatry [1-4]. Admission to hospital carries with it divergence from the familiar environment, getting together with strangers, social isolation and regression [5]. Preventing such a condition induced by admission should be one of the main goals of nursing care. This goal can only be achieved in a properly constituted therapeutic atmosphere, which is defined as an ideal and dynamic atmosphere aiming to cure patients, to raise self-confidence and selfvalue and to provide return to social life as soon as possible [6-8]. Social functionality is defined as ability for functionality of the subject at work, home, in social life and satisfying activities. In addition, it covers adequacy and satisfaction in roles as a partner, parent, friend and workfellow $[7,9]$. Deterioration in social functionality appears in diagnostic criteria of some psychiatric disorders such as schizophrenia and bipolar affective disorder and it is important in terms of prognosis of the disease $[6,10]$. Drug therapy, alone, is not enough for improving a patient's social functionality level [7]. Besides, patients should be socially supported. In order to provide this support, some special applications and arrangements may be carried out in the living area of the patient [11-13]. Those arrangements should improve social abilities of the patients by the help of self-confidence and self-value and should enable patients to feel safe $[14,15]$. Therapeutic atmosphere has dimensions relating to a patient's clothing and many other components from activity in the clinic to team members of the treatment $[4,14,16,17]$. Therapeutic atmosphere also increases socialization of patients by interaction between the patient and the team members and by consistent communication $[12,18]$. Besides this, it limits some behaviour such as harming oneself or others, non adherence to the treatment, substance abuse, unsuitable sexual desire and regress [17,19-22]. Therapeutic atmosphere gives patients an opportunity to be responsible for their own choices and to make this a part of their lives by giving the right "to make choice". In a therapeutic atmosphere with the main principles of "interaction based on trust", it should be the goal to improve an individual's social functionality and to make it sustainable in treatment and care $[6,21]$. As it is seen, functions in social functionality and functions aimed to be acquired in therapeutic atmosphere resemble each other. Furthermore, a structured ward atmosphere is thought to be effective in regaining these abilities of the patients with impaired social functionality. According to this, patients should be supported in terms of social parts besides drug therapy. It is crucial to determine the qualifications of this support via studies reflecting point of view of both patients and health professionals in the team. Therefore, the aim of the study was to evaluate the effect of therapeutic atmosphere on social functionality of the patients in a psychiatry clinic. So, some answers will be sought for the following research questions:

\section{Research Questions}

Is there a correlation between therapeutic atmosphere and social functionality? 
Is there a correlation between socio-demographic characteristics of patients and social functionality?

Is there a correlation between disease data and social functionality?

\section{Methods}

\section{Design}

This research was planned to be a cross-sectional study aiming at analyzing the relation between therapeutic atmosphere and social functioning in psychiatric patients and Psychiatric Clinic of Akdeniz University Hospital.

\section{Specifications of clinical atmosphere}

The ground floor of the clinic consists of two parts. In one part, patient interviewing rooms, secretariat room of the clinic, visit room, group therapy room and a waiting room exist. Then there is an entrance to a second part from the door opened by a card system. In the second part there are a multi-functional hall, occupation room, kitchen, exercise room, lavatories, assembly line for food service and a phone for patients. The other part of the hall is used as a dining hall. There is access from hall to the first floor in which patient rooms coated with tempered glass from base to ceiling. There is not a separate smoking room in the clinic; patients can smoke only in the sitting group part of the hall while accompanying people and staff smoke outside the clinic. Cleaning materials are stored in a locked room. While lecturers and research assistants are responsible for a certain number of patients, nurses are responsible for all of their care and treatment. Nurses do work-sharing and conduct short interviews with the patients, if necessary. Additionally, nurses also accompany the patients in group activities in the clinic, in good morning meetings, eating hours, visiting hours, and on trips from time to time. An activity program is performed every week in the clinic and it is announced on a billboard on the ground floor for both patients and team members. "Forwarding to work" and "good morning" meetings are done within the scope of activity program by psychiatric nursing. Also, patients are given some responsibilities in activities such as food preparation, putting on clothes, coin collection and management of the expenditure.

\section{Sample, setting and data collection}

The universe of the research is composed of all in-patients treated in Psychiatry Clinic of Akdeniz University Hospital. The annual patient admission rate is 278 in this psychiatry clinic. Sampling was done with "sampling with known universe" method. The sample was calculated as at least 47 with an accepted incidence of 50\%, standard deviation of $5 \%$ and confidence interval of $95 \%$ due to unknown prevalence and 50 patients who agreed to participate were recruited to the study.

Data were collected with descriptive form (Supplementary 1) developed by the researcher in order to determine the sociodemographic characteristics of the patients, properties of the disease and information about admission, with the "Ward Atmosphere Scale (WAS)" used to measure the perception of therapeutic atmosphere by the patients and to assess the atmosphere (Supplementary 2) and with the "Social Functionality Scale(SFS)" used to evaluate social roles and role functions of the patients (Supplementary 3). WAS was developed by R.H. Moss in 1974 to evaluate the ward atmosphere and to measure the perception of treatment atmosphere by both patients and staff. The validity and reliability study was done by Bozkurt [23]. The Turkish reliability and validity study was conducted by Erakay [24]. A pilot test was performed with 10 in-patients of a psychiatry clinic in order to assess the comprehensibility of the questions included in descriptive form, the WAS and SFS. The data of patients participated in the pilot test were not included in research findings.

\section{Ward Atmosphere Scale (WAS)}

Ward Atmosphere Scale, treatment environment, patients and employees to measure the perception of direction, in order to evaluate the service environment, in 1974, RH Moss has been developed by. Validity and reliability by Bozkurt in 1998. Scale relationships, personality development and operation of the system in three dimensions, and these dimensions contained in the 10 sub-scale consists of 100 items. Booth reliability coefficients of the subscales ranged from 0.51-0.74 reported. There is no cut-off point of the scale; not obtained a total score and the mean score for each subscale is taken [21].

\section{Social Functioning Scale (SFS)}

Social Functioning Scale, Birchwood et al. was developed in 1990. Reliability and validity study of the scale in our country is made by Erakay [22]. SFS basic skills, social behavior and quantitatively evaluates the performance also from the lack of lack of competence can be distinguished. Scale of seven sub-areas consist of: social engagement / social withdrawal (spending time alone, conversation, beginning to social recessive), interpersonal behavior (friends the number of heterosexual relationships, quality of communication), the premise of social events (common social activities in a range of occupational and sport, disco), leisure activities (hobbies, interests), independence-competence (independent living abilities required for ability to perform), independence-performance (live independently abilities required for ability to perform) and business / profession (with a productive work dealing or daily structured program of activities to do) [22]. In the reliability analysis of the scale Cronbach's alpha internal consistency coefficient was calculated as 0.807. Each sub-scale total score from the high level of functionality suggests that the shift towards a positive [22].

\section{Analysis}

The data of the present study were collected four times in different periods. Figure 1 shows the data collection process, location and tools. The data were analyzed by the SPSS 15.0 (SPSS Inc.,Chicago, II., USA) programme package. Total scores of scales of the patients were calculated using the SPSS program. Number and percentage in assessment of demographic data, Friedman test used in repeated measures for comparison of SFS for three different times, Kruskall Wallis test for evaluating the relation between mean SFS score and socio-demographic data and disease data and Pearson correlation for assessing the relation between scores of SFS and WAS were used.

\section{Ethical issues}

Prior to the research, Ethics Committee approval was received from Medical Faculty of Akdeniz University. Written permissions for performing the research were received from Akdeniz University Hospital. 


\section{Results}

The mean age of the participants was $33.70 \pm 7.92$ years; of them $60 \%$ were female, $50 \%$ were single/never-married and $56 \%$ were graduates from elementary/secondary school, $78 \%$ of the patients did not work in a job and perceived income level of $70 \%$ were moderate/ low. Of the patients, $43 \%$ had bipolar disorder-maniac episodes, $30 \%$ had schizophrenia and other psychotic disorders and $27 \%$ had depression diagnosis based on DSM-IV-TR criteria and the illness of the patients had lasted for $1.98 \pm 2.06$ years while $60 \%$ had his/her first admission to the hospital and $60 \%$ had an accompanying person. The evaluations of the participants about ward atmosphere were obtained on the 10th day of admission (Figure 1). Mean sub-scale scores of WAS were as follows; Participation (Involvement): $6.80 \pm 2.38$, Support: $6.20 \pm 1.42$, Spontaneizm: $5.30 \pm 1.35$, Autonomy: $5.40 \pm$ 1.64, Practical Orientation (Intention): $6.60 \pm 1.78$, Personal Problem Orientation (Intention): $5.48 \pm 0.81$, Anger and Aggression: $3.94 \pm$ 1.20 , Order and Organization: $6.24 \pm 1.90$, Clarity of the Program: 6.30 \pm 0.46 , Control of the Staff: $5.20 \pm 2.29$. With reference to those scores, the mean score of WAS was found to be superior.

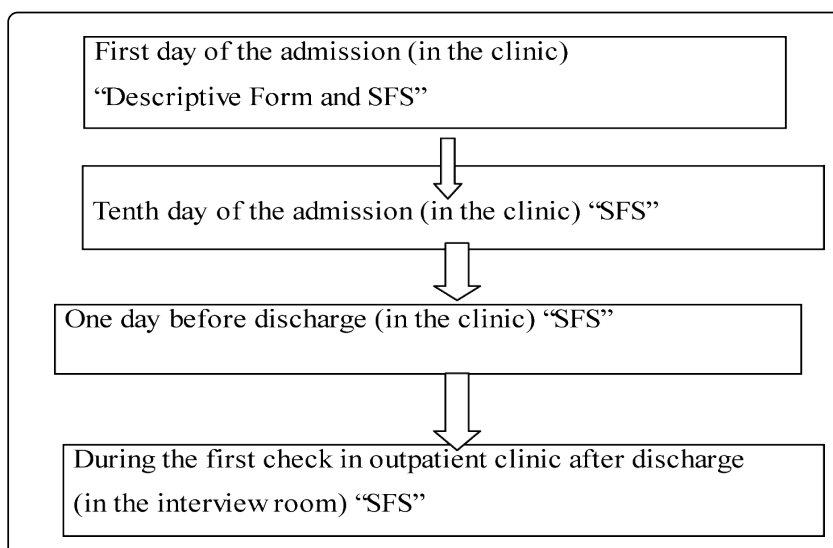

Figure 1: Data Collection Process
Table 1 shows Friedman test results of mean scores of sub-scales of SFS and evaluations of the 1st measurement (first day of admission), the 2nd measurement (discharge day) and the 3rd measurement (first out-patient clinic control). It was found that mean sub-scale scores of SFS in the 1st, 2nd and 3rd measurements were $101.32 \pm 38.38,105.14$ \pm 34.05 and $125.28 \pm 33.98$, respectively. It was determined that mean SFS scores after three separate evaluations were statistically significantly different in which the difference resulted from the 3rd measurement according to Friedman test results. Therefore, it may be concluded that social functionality of the patients increased gradually from admission and maintained increasingly during first control after discharge. When socio-demographic and disease data and repeated measurement scores of sub-scale of SFS were examined, it was determined that there was a significant between gender and medical diagnosis with social functionality for three repeated measurements. The mean score of male patients increased gradually by the first measurement, however the mean score of female patients increased very little in the last measurement compared to the first one (Table 2). Due to the aim of determining the effect of ward atmosphere on social functionality in the present research, the relation between SFS and WAS was examined only in the second measurement of SFS. When scores of WAS were reviewed, it was determined that patients evaluated the atmosphere superior to the average in terms of Participation, Spontaneizm, Autonomy, Practical Intention, Anger and Aggression, Order and Organization, Clarity of the Program, Control of the Staff. Scores of WAS applied on the 10th day of admission and SFS scores applied on the discharge day were compared in order to determine the effect of this atmosphere on social functionality of patients and it was found there was a significant relationship. There was a positive correlation between sub-dimensions of SFS - except for "Occupation/Profession"-and perception regarding ward atmosphere. It was also determined that Participation was positively and strongly correlated with spare-time activities $(\mathrm{r}=0.747, \mathrm{p}=0.00)$ while Spontaneizm was positively and moderately correlated with interpersonal functionality, spare-time activities and independence (competence) (Table 3).

\begin{tabular}{|c|c|c|c|c|}
\hline Social Functionality Scale & $\begin{array}{l}\text { 1st Measurement (First day of } \\
\text { admission) Mean Rank } X \pm S D\end{array}$ & $\begin{array}{l}\text { 2nd Measurement (Discharge day) } \\
\text { Mean Rank X } \pm \text { SD }\end{array}$ & $\begin{array}{l}\text { 3rd Measurement (First out-patient } \\
\text { clinic control) Mean Rank } X \pm S D\end{array}$ & $\mathrm{p}$ \\
\hline Social Regress & $\begin{array}{l}1.38 \\
7.00 \pm 3.09\end{array}$ & $\begin{array}{l}1.90 \\
7.76 \pm 2.98\end{array}$ & $\begin{array}{l}2.72 \\
9.02 \pm 2.90\end{array}$ & $\mathrm{p}=0.000^{*}$ \\
\hline Interpersonal Functionality & $\begin{array}{l}1.54 \\
4.34 \pm 1.47\end{array}$ & $\begin{array}{l}1.79 \\
4.90 \pm 1.21\end{array}$ & $\begin{array}{l}2.67 \\
5.68 \pm 1.53\end{array}$ & $\mathrm{p}=0.000^{*}$ \\
\hline Social Activities & $\begin{array}{l}1.50 \\
29.98 \pm 12.49\end{array}$ & $\begin{array}{l}1.90 \\
29.82 \pm 10.97\end{array}$ & $\begin{array}{l}2.60 \\
33.54 \pm 10.70\end{array}$ & $\mathrm{p}=0.000^{*}$ \\
\hline Spare Time Activities & $\begin{array}{l}1.60 \\
20.36 \pm 8.38\end{array}$ & $\begin{array}{l}1.66 \\
20.26 \pm 7.27\end{array}$ & $\begin{array}{l}2.74 \\
23.48 \pm 7.96\end{array}$ & $p=0.000^{*}$ \\
\hline Independence (Competence) & $\begin{array}{l}1.43 \\
18.08 \pm 8.01\end{array}$ & $\begin{array}{l}1.81 \\
18.78 \pm 8.16\end{array}$ & $\begin{array}{l}2.76 \\
21.60 \pm 8.16\end{array}$ & $\mathrm{p}=0.000^{*}$ \\
\hline Independence (Performance) & $\begin{array}{l}1.33 \\
18.26 \pm 7.01\end{array}$ & $\begin{array}{l}1.83 \\
20.08 \pm 6.94\end{array}$ & $\begin{array}{l}2.84 \\
22.16 \pm 6.25\end{array}$ & $\mathrm{p}=0.000^{*}$ \\
\hline Occupation/ & 1.54 & 1.84 & 2.62 & $\mathrm{p}=0.000^{*}$ \\
\hline Profession & $3.30 \pm 1.11$ & $3.54 \pm 1.05$ & $4.12 \pm 0.87$ & \\
\hline SFS Total Score & $\begin{array}{l}1.19 \\
101.32 \pm 38.38\end{array}$ & $\begin{array}{l}1.81 \\
105.14 \pm 34.05\end{array}$ & $\begin{array}{l}3.00 \\
125.28 \pm 33.98\end{array}$ & $p=0.000^{*}$ \\
\hline
\end{tabular}

Table 1: Distribution of social functionality scale overall and subscale scores according to repeated measurements 
Citation: Lok N, Buldukogl K (2015) Effect of Therapeutic Atmosphere in a Psychiatry Clinic on Social Functionality of in-Patients. J

\begin{tabular}{|c|c|c|c|c|c|c|}
\hline Variables & $\begin{array}{l}\text { 1st Measurement (First day of } \\
\text { admission) } \\
\mathrm{X} \pm \mathrm{SD}\end{array}$ & Test value & $\begin{array}{l}\text { 2nd Measurement } \\
\text { (Discharge day) X } \pm \\
\text { SD }\end{array}$ & Test value & $\begin{array}{l}\text { 3rd Measurement (First out- } \\
\text { patient clinic control) } X \pm S D\end{array}$ & Test value \\
\hline \multicolumn{7}{|l|}{ Gender } \\
\hline Female & $21.43 \pm 7.58$ & \multirow[t]{2}{*}{$p=0.01$} & $22.05 \pm 6.18$ & \multirow[t]{2}{*}{$p=0.04$} & $21.90 \pm 6.32$ & \multirow[t]{2}{*}{$p=0.03$} \\
\hline Male & $31.60 \pm 6.74$ & & $30.68 \pm 4.37$ & & $30.90 \pm 2.48$ & \\
\hline \multicolumn{7}{|l|}{ Marital Status } \\
\hline Married & $23.44 \pm 6.41$ & \multirow[t]{3}{*}{$p=0.75$} & $22.78 \pm 6.26$ & \multirow[t]{3}{*}{$p=0.51$} & $20.64 \pm 8.61$ & \multirow[t]{3}{*}{$p=0.17$} \\
\hline $\begin{array}{l}\text { Single/ } \\
\text { Never-Married }\end{array}$ & $26.76 \pm 4.23$ & & $27.82 \pm 5.78$ & & $29.02 \pm 2.46$ & \\
\hline Divorced & $26.29 \pm 9.36$ & & $24.21 \pm 5.42$ & & $25.43 \pm 7.82$ & \\
\hline \multicolumn{7}{|l|}{$\begin{array}{l}\text { Education } \\
\text { Status }\end{array}$} \\
\hline $\begin{array}{l}\text { Elementary/ } \\
\text { Secondary }\end{array}$ & $24.57 \pm 7.45$ & \multirow[t]{2}{*}{$\mathrm{p}=0.61$} & $24.20 \pm 6.65$ & \multirow[t]{2}{*}{$p=0.48$} & $24.50 \pm 7.52$ & \multirow[t]{2}{*}{$p=0.58$} \\
\hline $\begin{array}{l}\text { High School and } \\
\text { higher }\end{array}$ & $26.68 \pm 8.64$ & & $27.16 \pm 4.47$ & & $26.77 \pm 6.45$ & \\
\hline \multicolumn{7}{|l|}{ Working Status } \\
\hline Working & $25.29 \pm 4.42$ & \multirow[t]{2}{*}{$p=0.95$} & $23.67 \pm 4.63$ & \multirow[t]{2}{*}{$p=0.62$} & $23.71 \pm 9.01$ & \multirow[t]{2}{*}{$p=0.63$} \\
\hline Not working & $25.57 \pm 6.24$ & & $26.08 \pm 3.34$ & & $26.07 \pm 3.14$ & \\
\hline \multicolumn{7}{|l|}{$\begin{array}{l}\text { Perceived Income } \\
\text { Level }\end{array}$} \\
\hline $\begin{array}{l}\text { Very Well/ } \\
\text { Well }\end{array}$ & $20.93 \pm 5.43$ & \multirow[t]{2}{*}{$p=0.15$} & $18.30 \pm 8.63$ & \multirow[t]{2}{*}{$p=0.22$} & $20.27 \pm 6.78$ & \multirow[t]{2}{*}{$p=0.09$} \\
\hline $\begin{array}{l}\text { Moderate/ } \\
\text { Low }\end{array}$ & $27.46 \pm 6.48$ & & $28.59 \pm 6.81$ & & $27.74 \pm 4.15$ & \\
\hline \multicolumn{7}{|l|}{$\begin{array}{l}\text { Living Place for Long } \\
\text { Time }\end{array}$} \\
\hline Metropolis & $25.36 \pm 6.25$ & \multirow[t]{2}{*}{$p=0.83$} & $25.47 \pm 7.23$ & \multirow[t]{2}{*}{$p=0.96$} & $25.73 \pm 6.07$ & \multirow[t]{2}{*}{$p=0.73$} \\
\hline City/Town & $26.80 \pm 4.06$ & & $25.80 \pm 4.46$ & & $23.40 \pm 5.94$ & \\
\hline \multicolumn{7}{|l|}{ Medical Diagnosis* } \\
\hline $\begin{array}{ll}\text { Schizophrenia and } \\
\text { other } & \text { psychotic } \\
\text { disorders } & \end{array}$ & $28.42 \pm 3.61$ & \multirow[t]{3}{*}{$p=0.00$} & $30.24 \pm 6.41$ & \multirow[t]{3}{*}{$p=0.00$} & $29.72 \pm 6.43$ & \multirow[t]{3}{*}{$p=0.00$} \\
\hline $\begin{array}{l}\text { Bipolar disorder } \\
\text { (maniac episode) }\end{array}$ & $43.00 \pm 6.09$ & & $40.40 \pm 3.33$ & & $41.40 \pm 5.08$ & \\
\hline Depression & $8.58 \pm 4.13$ & & $9.62 \pm .49$ & & $11.92 \pm 9.15$ & \\
\hline \multicolumn{7}{|l|}{ Number of admissions } \\
\hline First & $23.68 \pm 6.17$ & \multirow[t]{2}{*}{$p=0.28$} & $23.63 \pm 7.47$ & \multirow[t]{2}{*}{$p=0.26$} & $24.12 \pm 8.69$ & $p=0.41$ \\
\hline More than one & $28.22 \pm 3.45$ & & $28.30 \pm 4.32$ & & $27.58 \pm 3.26$ & \\
\hline Accompanying person & & & & & & \\
\hline Present & $26.90 \pm 4.42$ & $p=0.41$ & $26.68 \pm 6.21$ & $p=0.48$ & $26.28 \pm 3.62$ & $p=0.64$ \\
\hline Absent & $23.40 \pm 7.08$ & & $23.72 \pm 7.52$ & & $24.32 \pm 5.56$ & \\
\hline
\end{tabular}

Table 2: Distribution of Repeated Measures Scores of Total Scales of Social Functionality Scale and Socio-Demographic and Disease Characteristics of the Subjects (KW), ${ }^{\star}$ Classified based on DSM IV diagnostic criteria. 
Citation: Lok N, Buldukogl K (2015) Effect of Therapeutic Atmosphere in a Psychiatry Clinic on Social Functionality of in-Patients. J Psychiatry 18: 195. doi:10.4172/2378-5756.1000195

Page 5 of 7

\begin{tabular}{|c|c|c|c|c|c|c|c|}
\hline \multicolumn{8}{|c|}{ Social Functionality Scale (Second Measurement) } \\
\hline $\begin{array}{l}\text { Ward Atmosphere } \\
\text { Scale }\end{array}$ & $\begin{array}{l}\text { Social } \\
\text { Regression }\end{array}$ & $\begin{array}{l}\text { Interpersonal } \\
\text { Functionality }\end{array}$ & $\begin{array}{l}\text { Social } \\
\text { Activities }\end{array}$ & $\begin{array}{l}\text { Spare time } \\
\text { activities }\end{array}$ & $\begin{array}{l}\text { Independence } \\
\text { (Competence) }\end{array}$ & $\begin{array}{l}\text { Independence } \\
\text { (Performance) }\end{array}$ & Occupation/Profession \\
\hline Participation & $\begin{array}{l}-0.117 \\
0.42\end{array}$ & $\begin{array}{l}-0.047 \\
0.74\end{array}$ & $\begin{array}{l}-0.060 \\
0.68\end{array}$ & $\begin{array}{l}0.747 \\
0.00^{\star \star}\end{array}$ & $\begin{array}{l}-0.159 \\
0.27\end{array}$ & $\begin{array}{l}-0.019 \\
0.89\end{array}$ & $\begin{array}{l}-0.356 \\
0.46\end{array}$ \\
\hline Support & $\begin{array}{l}-0.040 \\
0.78\end{array}$ & $\begin{array}{l}-0.001 \\
0.99\end{array}$ & $\begin{array}{l}-0.070 \\
0.63\end{array}$ & $\begin{array}{l}0.251 \\
0.08\end{array}$ & $\begin{array}{l}0.102 \\
0.48\end{array}$ & $\begin{array}{l}0.069 \\
0.63\end{array}$ & $\begin{array}{l}0.278 \\
0.78\end{array}$ \\
\hline Spontaneizm & $\begin{array}{l}-0.297 \\
0.03^{*}\end{array}$ & $\begin{array}{l}0.663 \\
0.00^{\star *}\end{array}$ & $\begin{array}{l}-.0 .367 \\
0.00^{* *}\end{array}$ & $\begin{array}{l}0.650 \\
0.00^{\star *}\end{array}$ & $\begin{array}{l}0.510 \\
0.00^{\star *}\end{array}$ & $\begin{array}{l}-0.350 \\
0.01^{*}\end{array}$ & $\begin{array}{l}-0.356 \\
0.56\end{array}$ \\
\hline Autonomy & $\begin{array}{l}0.874 \\
0.00^{* *}\end{array}$ & $\begin{array}{l}0.683 \\
0.00^{\star *}\end{array}$ & $\begin{array}{l}0.037 \\
0.80\end{array}$ & $\begin{array}{l}0.586 \\
0.00^{\star *}\end{array}$ & $\begin{array}{l}0.845 \\
0.00^{\star \star}\end{array}$ & $\begin{array}{l}0.081 \\
0.57\end{array}$ & $\begin{array}{l}0.654 \\
0.78\end{array}$ \\
\hline Practical Intention & $\begin{array}{l}-0.244 \\
0.08\end{array}$ & $\begin{array}{l}0.746 \\
0.00^{\star *}\end{array}$ & $\begin{array}{l}-0.386 \\
0.00^{\star \star}\end{array}$ & $\begin{array}{l}0.767 \\
0.00^{* *}\end{array}$ & $\begin{array}{l}-0.406 \\
0.00^{\star \star}\end{array}$ & $\begin{array}{l}-0.376 \\
0.00^{\star *}\end{array}$ & $\begin{array}{l}-0.651 \\
0.45\end{array}$ \\
\hline $\begin{array}{l}\text { Personal } \\
\text { Orientation }\end{array}$ & $\begin{array}{l}0.028 \\
0.84\end{array}$ & $\begin{array}{l}0.106 \\
0.46\end{array}$ & $\begin{array}{l}0.034 \\
0.81\end{array}$ & $\begin{array}{l}-0.036 \\
0.80\end{array}$ & $\begin{array}{l}0.050 \\
0.731\end{array}$ & $\begin{array}{l}-0.879 \\
0.24\end{array}$ & $\begin{array}{l}-0.124 \\
0.73\end{array}$ \\
\hline Anger and Aggression & $\begin{array}{l}-0.757 \\
0.00^{\star *}\end{array}$ & $\begin{array}{l}0.001 \\
0.99\end{array}$ & $\begin{array}{l}0.210 \\
0.14\end{array}$ & $\begin{array}{l}-0.879 \\
0.00^{\star *}\end{array}$ & $\begin{array}{l}0.201 \\
0.16\end{array}$ & $\begin{array}{l}0.115 \\
0.42\end{array}$ & $\begin{array}{l}0.478 \\
0.42\end{array}$ \\
\hline Order and Organization & $\begin{array}{l}-0.239 \\
0.09\end{array}$ & $\begin{array}{l}-0.195 \\
0.17\end{array}$ & $\begin{array}{l}-0.338 \\
0.01^{*}\end{array}$ & $\begin{array}{l}-0.378 \\
0.00^{\star *}\end{array}$ & $\begin{array}{l}-0.461 \\
0.00^{\star *}\end{array}$ & $\begin{array}{l}0.257 \\
0.07\end{array}$ & $\begin{array}{l}0.328 \\
0.35\end{array}$ \\
\hline Clarity of the Program & $\begin{array}{l}-0.78 \\
0.59\end{array}$ & $\begin{array}{l}0.518 \\
0.00^{* *}\end{array}$ & $\begin{array}{l}-.0 .012 \\
0.93\end{array}$ & $\begin{array}{l}0.619 \\
0.00^{* *}\end{array}$ & $\begin{array}{l}0.498 \\
0.00^{\star \star}\end{array}$ & $\begin{array}{l}0.077 \\
0.59\end{array}$ & $\begin{array}{l}-0.357 \\
0.29\end{array}$ \\
\hline Control of the Staff & $\begin{array}{l}-0.281 \\
0.41\end{array}$ & $\begin{array}{l}-0.142 \\
0.32\end{array}$ & $\begin{array}{l}-0.324 \\
0.02^{*}\end{array}$ & $\begin{array}{l}-0.265 \\
0.06\end{array}$ & $\begin{array}{l}-0.421 \\
0.00^{\star *}\end{array}$ & $\begin{array}{l}-0.284 \\
0.40\end{array}$ & $\begin{array}{l}0.852 \\
0.84\end{array}$ \\
\hline
\end{tabular}

Table 3: Correlation between Mean Scores of WAS and SFS (Second Measurement) of the Subjects (r, p) ${ }^{*} \mathrm{p}<0.05,{ }^{* *} \mathrm{p}<0.001$

\section{Discussion}

In the present study, the effect of therapeutic atmosphere on social functionality was investigated and the current atmosphere of the relevant psychiatric clinic was found to increase social functionality. The most important finding of the present study has been that male patients were more socially functional than female patients and that functionality was maintained for one month after discharge. Besides this, mean SFS scores significantly differed based on patients' medical diagnosis in three repeated measurements and differences resulted from the third, which showed also that whatever the diagnosis was, the level of functionality of the patients after discharge was higher than with disease onset and during clinic admission. Relevant studies have shown that a well-structured ward atmosphere increases social functionality of patients $[11,12,17,25,26]$. In this respect, it seems that the relevant ward's atmosphere-despite having requirement to be improved - contributed to the development in patients' social functionality.

Mean score of SFS sub-scale of the patients significantly differed in the first, second and third measurements. It was found that mean SFS scores on the first day of admission (1st measurement) significantly increased in the second (discharge day) and third (first out-patient clinic control) measurements. The highest mean score of SFS was 
detected in the third measurement (Table 1). There are some changes in the patients who have been in a well-structured therapeutic atmosphere such as alleviation in disease symptoms, increase in insight, becoming stronger for coping, improvement in problem solving and communication skills, development in self-confidence, provision of realistic personal goals, decrement in the factors impairing social adaptation and causing ability loss [17,21,26-29]. The lowest score of social functionality on the first day of admission may result from not having been in the therapeutic atmosphere yet and increase of the second measurement of social functionality may be explained by having been in the therapeutic atmosphere for at least 10 days and having participated in all activities. Meanwhile patients saw that they were not alone, others also had similar problems, and they learnt to share and to trust other people, which could contribute to improvement in social functionality. The highest level of social functionality in the third measurement gave rise to thought that acquired properties such as interpersonal functionality, participation in the social activities and spare-time activities helped maintain social functionality of patients after discharge.

The present study has also revealed that socio-demographic characteristics and disease data of the patients were significantly different between SFS scores in three measurements and mean SFS scores of men were higher than women (Table 2). This finding is parallel with the literature [26,30,31]. Majority of the female participants were housewives. The lower level of social functionality of female patients could be explained by the social status of the women in Turkish society. As in many other societies, the status of women had been limited to the house for years while their job had been determined as raising children [32,33]. Almost all cultures behave differently to boys and girls. During the socialization process, girls desired to be obedient, mild and selfless whereas boys are desired to be competitive, dashing and enterprising and those characteristics are strengthened $[5,32,35]$. Determining the limitations of the roles in this manner, gender role patterns of women and men are internalized. Women patients remaining in the background during the ward activities and being distant from other patients, but on the other hand, male patients being active and enterprising in the ward atmosphere could be related to gender role patterns learnt during the socialization period.

Medical diagnosis of the patients was found to significantly differ from mean SFS scores of three repeated measurements (Table 1). While the mean SFS scores of three repeated measurements gradually increased in all diagnosed patients, mean score of SFS patients with depression was lower than patients with other diagnoses. Fatigue, exhaustion, energy loss (dissipation), social isolation, anhedonia, and regression, which are the symptoms occurring during the prognosis of depression [35] may have led to a lower social functionality level in this group. A higher mean SFS score of patients with bipolar disorder measured during admission may result from the resemblance of some symptoms such as increase in social relations, participation, anger and aggression, which are also parts of the prognosis of bipolar disorder (manic episode) [36-38] with features evaluated under the subdimensions of SFS [31]. Remarkably, the mean SFS score on the discharge day was lower than on the admission day of those patients with bipolar disorder, which may be due to attenuation of disease symptoms, which causes a high SFS score, by the ward atmosphere and by the effect of treatment showing a favourable result.

Another interesting result of the present study was significant correlation between perception of patients regarding ward atmosphere and social functionality level of them. Participation that is a sub-scale of WAS was significantly and positively correlated with spare-time activities. Ward atmosphere should enable patients to be active, willing, excited and to feel part of the team soul during the spare-time activities when they spend time with each other, personal and social [39-42]. This finding is parallel with the literature.

\section{Conclusion}

In the present study, the effect of therapeutic atmosphere on social functionality was investigated and the current atmosphere of the relevant psychiatric clinic was found to increase social functionality. The most important finding of the present study has been that male patients were more socially functional than female patients and that functionality was maintained for one month after discharge. Besides this, mean SFS scores significantly differed based on patients' medical diagnosis in three repeated measurements and difference resulted from the third, which showed also that whatever the diagnosis was, the level of functionality of the patients after discharge was higher than during disease onset and during clinic admission.

\section{Recommendations}

Accordingly, it is suggested to evaluate therapeutic atmosphere in psychiatry clinics and it's relation with functionality of the patients frequently as needed and to make revisions and amendments based on data of that evaluation and to take this up seriously as an institutional policy.

\section{Limitations of the Study}

Study findings are limited to psychiatric patients under treatment of Akdeniz University Psychiatry Clinic who agreed to participate in the study. Study findings cannot be generalized to all psychiatry patients.

\section{Acknowledgement}

We acknowledge all the nurses and physicians of Akdeniz University Psychiatry Clinic who have not preserved their assistance for study.

\section{References}

1. Burns T, Catty J, White S, Becker T, Koletsi M, et al. (2009) The impact of supported employment and working on clinical and social functioning: results of an international study of individual placement and support. Schizophr Bull 35: 949-958.

2. APA (American Psychiatric Association) (2007) DSM-IV-TR Diagnostic Criteria Reference Manual. E Köroglu translation editor to Turkish. Hekimler Yayin Birligi: Ankara.

3. Carpenito-Moyet LJ (2005) Nursing Diagnosis Manual. (Translator: Erdemir F.) Nobel Tip Press. Ankara 359-362.

4. Krychman M, Millheiser LS (2013) Sexual health issues in women with cancer. J Sex Med 10 Suppl 1: 5-15.

5. Videbeck SL (2011) Psychiatric-mental health nursing. Wolters Kluwer Health 83-88.

6. Southard K, Jarrell A, Shattell MM, McCoy TP, Bartlett R, et al. (2012) Enclosed versus open nursing stations in adult acute care psychiatric settings: does the design affect the therapeutic milieu? J Psychosoc Nurs Ment Health Serv 50: 28-34.

7. Szanto K, Dombrovski AY, Sahakian BJ, Mulsant BH, Houck PR, et al. (2012) Social emotion recognition, social functioning, and attempted suicide in late-life depression. Am J Geriatr Psychiatry 20: 257-265. 
Citation: Lok N, Buldukogl K (2015) Effect of Therapeutic Atmosphere in a Psychiatry Clinic on Social Functionality of in-Patients. J

8. English T, John OP, Srivastava S, Gross JJ (2012) Emotion Regulation and Peer-Rated Social Functioning: A Four-Year Longitudinal Study. J Res Pers 46: 780-784.

9. Mohr WK (2003) Psychiatric-Mental Health Nursing. Philadelphia: Lippincott Williams \& Wilkins.(5th edn):451-453.

10. Stuart GW, Laraia MT (2005) Principles and Practice of Psychiatric Nursing. 8th Edition. Mosby, Inc. All rights reserved. 700-703.

11. Lewin TJ, Carr VJ, Conrad AM, Sly KA, Tirupati S, et al. (2012) Shift climate profiles and correlates in acute psychiatric inpatient units. Soc Psychiatry Psychiatr Epidemiol 47: 1429-1440.

12. Coombs T, Crookes P, Curtis J (2013) A comprehensive mental health nursing assessment: variability of content in practice. J Psychiatr Ment Health Nurs 20: 150-155.

13. Cornblatt BA, Carrión RE, Addington J, Seidman L, Walker EF, et al. (2012) Risk factors for psychosis: impaired social and role functioning. Schizophr Bull 38: 1247-1257.

14. Shattell MM, Andes M, Thomas SP (2008) How patients and nurses experience the acute care psychiatric environment. Nurs Inq 15: 242-250

15. Fortinash K.M. \& Worret P.A.H. (2008) In: Fortinash KM and Worret PAH. Psychiatric Mental Health Nursing (4th edn) : 521-524.

16. Alexander J (2006) Patients' feelings about ward nursing regimes and involvement in rule construction. J Psychiatr Ment Health Nurs 13: 543-553.

17. Keltner NL, Schwecke LH, Bostrom CE (2003) Psychiatric Nursing. Fourth edition. 120-125

18. Ward L (2011) Mental health nursing and stress: maintaining balance. Int J Ment Health Nurs 20: 77-85

19. Townsend MC (2009) Psychiatric mental health nursing: Concepts of care in evidence-based practice. 6th Edition. F.A. Davis Co. Philadelphia. 195-203.

20. Oflaz F (2006) Concept of treating atmosphere in psychiatry clinic and responsibilities of the nurses. Anatolian Psychiatry Journal 7: 55-61.

21. Bozkurt SD (1998) Ward Atmosphere Scale (WAS) Validity and Reliability Study. Unpublished Master of Science Dissertation. Izmir, Ege University, Institute of HealthSciences.

22. Aydemir O,Köroglu E (2009) Clinic Measures Used in Psychiatry. HekimlerYayinBirligi. HYB Publications (4thedn) 76-81.

23. Burns T, Patrick D (2007) Social functioning as an outcome measure in schizophrenia studies. Acta Psychiatr Scand 116: 403-418.

24. Pinsonnault E1, Dubuc N, Desrosiers J, Delli-Colli N, Hébert R (2009) Validation study of a social functioning scale: The social-SMAF (socialFunctional Autonomy Measurement System). Arch Gerontol Geriatr 48: 40-44.

25. Haigh, R. (2013) The quintessence of a therapeutic environment, Therapeutic Communities: The International Journal of Therapeutic Communities 34: 6-15.

26. Sørlie T, Parniakov A, Rezvy G, Ponomarev O (2010) Psychometric evaluation of the Ward Atmosphere Scale in a Russian psychiatric hospital. Nord J Psychiatry 64: 377-383.
27. Tuvesson H, Wann-Hansson C, Eklund M (2011) The ward atmosphere important for the psychosocial work environment of nursing staff in psychiatric in-patient care. BMC Nurs 10: 12 .

28. Addington J, Saeedi H, Addington D (2006) Facial affect recognition: a mediator between cognitive and social functioning in psychosis? Schizophr Res 85: 142-150.

29. Erol A, KeleÅŸ Unal E, TunÃ $\S$ Aydin E, Mete L (2009) [Predictors of social functioning in schizophrenia]. Turk Psikiyatri Derg 20: 313-321.

30. Cimen L (2011) The effect of education as a factor on participation of the woman in infamily decisions. International Journal of New Trends in Arts, Sports \& ScienceEducation 278-90.

31. Vaskinn A, Sundet K, Simonsen C, Hellvin T, Melle I, et al. (2011) Sex differences in neuropsychological performance and social functioning in schizophrenia and bipolar disorder. Neuropsychology 25: 499-510.

32. Kuzgun Y, Sevim SA (2004) Relation between attitude towards women's working and religious orientation. Ankara University Journal of Educational Sciences Faculty 37: 14-27.

33. Iosifescu DV (2012) The relation between mood, cognition and psychosocial functioning in psychiatric disorders. Eur Neuropsychopharmacol 22 Suppl 3: S499-504.

34. Anderson IM, Haddad PM, Scott J (2012) Bipolar disorder. BMJ 345: e8508.

35. Mitchell PB (2012) Bipolar disorder: the shift to overdiagnosis. Can J Psychiatry 57: 659-665.

36. Alink LRA, Dante C, Jungmeen K (2012) Longitudinal associations among child maltreatment, social functioning, and cortisol regulation. Developmental Psychology, 48: 224-236.

37. Johnson S, Lloyd-Evans B, Morant N, Gilburt H, Shepherd G, et al (2010) Alternatives to standard acute in-patient care in England: roles and populations served. Br J Psychiatry Suppl 53: s6-6s13.

38. Long CG, Knight C, Bradley L, Thomas M (2012) Effective therapeutic milieus in secure services for women: the service user perspective. J Ment Health 21: 567-578.

39. Osborn DP, Lloyd-Evans B, Johnson S, Gilburt H, Byford S, et al. (2010) Residential alternatives to acute in-patient care in England: satisfaction, ward atmosphere and service user experiences. Br J Psychiatry Suppl 53: s41-45.

40. Røssberg JI, Friis S (2003) A suggested revision of the Ward Atmosphere Scale. Acta Psychiatr Scand 108: 374-380.

41. Millar D (2013). The therapeutic milieu under fire: security and insecurity in forensic mental health by John Adlam. Psychodynamic Practice: Individuals, Groups andOrganisation19: 336-338.

42. Killaspy H, Marston L, Omar RZ, Green N, Harrison I, et al. (2013) Service quality and clinical outcomes: an example from mental health rehabilitation services in England. Br J Psychiatry 202: 28-34. 